\title{
Uptake, metabolism, and distribution of DDT in organs of the blue crab, Callinectes sapidus
}

Peter F. Sheridan

College of William and Mary - Virginia Institute of Marine Science

Follow this and additional works at: https://scholarworks.wm.edu/etd

Part of the Marine Biology Commons, and the Terrestrial and Aquatic Ecology Commons

\section{Recommended Citation}

Sheridan, Peter F., "Uptake, metabolism, and distribution of DDT in organs of the blue crab, Callinectes sapidus" (1973). Dissertations, Theses, and Masters Projects. William \& Mary. Paper 1627407601. https://doi.org/10.25773/2XY0-0917

This Thesis is brought to you for free and open access by the Theses, Dissertations, \& Master Projects at W\&M ScholarWorks. It has been accepted for inclusion in Dissertations, Theses, and Masters Projects by an authorized administrator of W\&M ScholarWorks. For more information, please contact scholarworks@wm.edu. 
UPTAKE, METABOLISM, AND DISTRTBUTION OF DDT IN ORGANS OF THE BLUE CRAB, CALLINECTES SAPIDUS

Peten Francis Sheridan

Gloucester Point, Virginia

B.A., University of Virginia, 1971

A Thesis Presented to the Graduate Faculty of the University of Virginia

in Candidacy for the Degree of Master of Science

\author{
Department of Marine Science \\ University of Virginia
}




\section{APPROVAL SHEET}

This thesis is presented in partial fulfillment of the requirements for the degree of

\section{Master of Science}

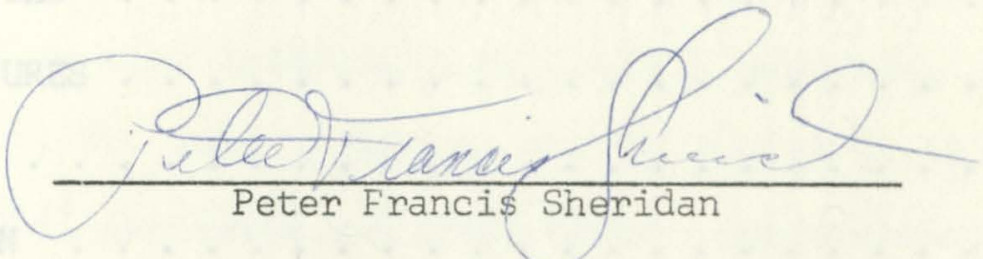

Approved, August, 1973

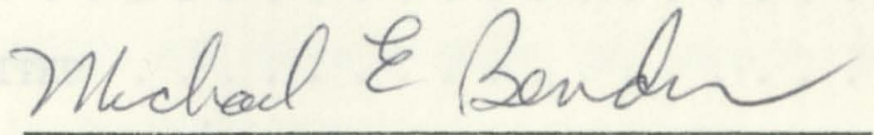

Michael E. Bender

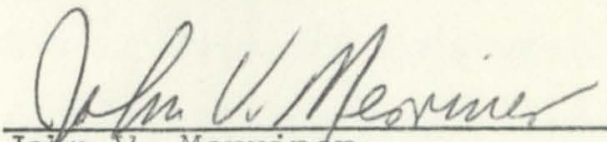

John V. Merriner
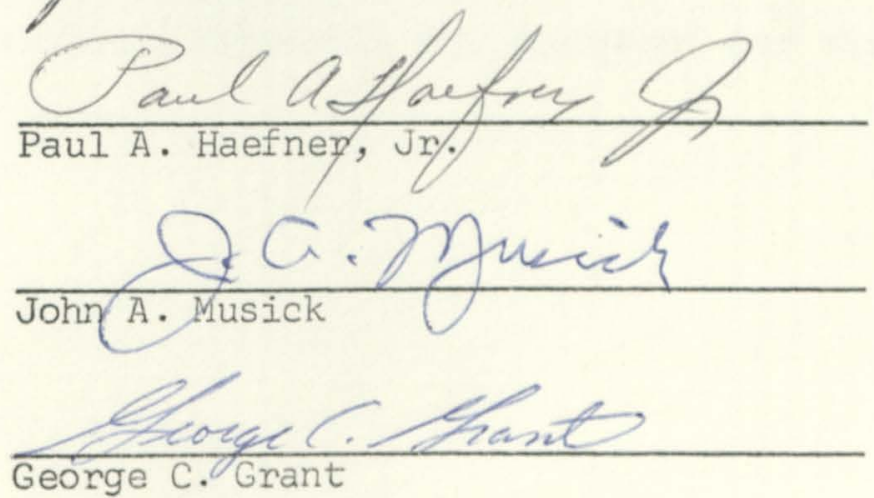
TABLE OF CONTENTS

Page

ACKNOWLEDGMENTS ........................... iv LIST OF TABLES . . . . . . . . . . . . . . . . . v v LIST OF FIGURES . . . . . . . . . . . . . . . . . vi vi ABSTRACT . . . . . . . . . . . . . . . . v vii

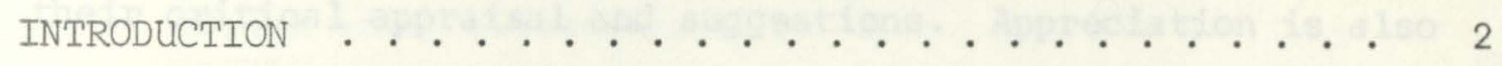
MATERIALS AND METHODS................ 5 RESULTS . . . . . . . . . . . . . . . . . . . 8 DISCUSSION . . . . . . . . . . . . . . . . . . 18 LITERATURE CITED . . . . . . . . . . . . . . . . 26

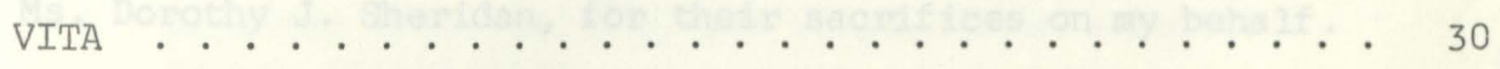




\section{ACKNOWLEDGMENTS}

I wish to express my appreciation to Dr. Michael E. Bender for acting as my major professor and for his support and encouragement. I am also indebted to Mr. John V. Merriner, Dr. Paul A. Haefner, Jr., Dr. John A. Musick, and Dr. George C. Grant for their critical appraisal and suggestions. Appreciation is also given to $\mathrm{Mr}$. Robert J. Huggett, Mr. Harold Slone, and Mr. Thomas A. Barnard for their technical advocacy.

Special thanks are given to my wife, Kathy, for her patience and understanding, and to my parents, Mr. John P. Sheridan and Ms. Dorothy J. Sheridan, for their sacrifices on my behalf .

I also wish to thank the Department of Ecology - Pollution of the Virginia Institute of Marine Science which supplied the necessary analytical materials and equipment for this study. 


\section{LIST OF TABLES}

Table

Page

1. DDT, DDD, and DDE residues observed in blue crab organs from the control population. . . . . . . . . .

2. DDT, DDD, and DDE residues observed in blue crab organs after 12 hour exposure to $0.01 \mathrm{ppm}$ DDT in water... . . . . . . . . . . . . . . .

3. DDT, DDD, and DDE residues observed in blue crab organs after 12 hour exposure to $0.1 \mathrm{ppm}$ DDT in water.............. . . . . . . . .

4. DDT, DDD, and DDE residues observed in blue crab organs after 12 hour exposure to $1.0 \mathrm{ppm}$ DDT in water......................

5. Reproductive condition of control and DDT-exposed blue crabs . . . . . . . . . . . . . . . . . .

6. Reported DDT, DDD, DDE, and total DDT in selected marine crustaceans. . . . . . . . . . . . . . . . .

7. DDT, DDD, DDE, and total DDT residues in blue crabs collected from the York River, Virginia, in July, August, and September, 1972 . 


\section{LIST OF FIGURES}

Figure

Page

1. DDT, DDD, and DDE residues observed in blue crab organs after a 12 hour exposure to $0.01 \mathrm{ppm}$ DDT . . . . 13

2. DDT, DDD, and DDE residues observed in blue crab organs after a 12 hour exposure to $0.1 \mathrm{ppm}$ DDT . . . . 14

3. DDT, DDD, and DDE residues observed in blue crab organs after a 12 hour exposure to $1.0 \mathrm{ppm} \mathrm{DDT} \mathrm{.} \mathrm{.} \mathrm{.} 15$ 


\section{ABSTRACT}

Metabolites of DDT were detected in five out of six major organs of blue crabs, Callinectes sapidus, taken from estuarine populations. Residue concentrations were highest in the hepatopancreas and below the limit of detection in the heart. Concentrations in pooled gonad samples (ovaries + testes) depended on the stage of development of the ovaries. Residue levels were low in claw and backfin muscles.

Adult blue crabs were exposed for 12 hours to $0.01,0.1$, and $1.0 \mathrm{ppm}$ DDT in water. No significant mortality was recorded. DDT was absorbed through the gills and transported to the hepatopancreas via the hemolymph. Biotransformation and distribution of DDT and its metabolites was regulated by the hepatopancreas. Induction of metabolic transformation of DDT to DDD and DDE occurred immediately. Storage of residues was greatest in the hepatopancreas and developing ovaries. Rates of loss of DDT residues from organs was subject to considerable variation. 


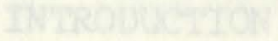

UPTAKE, METABOLISM, AND DISTRIBUTION OF DDT BY ORGANS OF THE BLUE CRAB, CALLINECTES SAPIDUS 


\section{INTRODUCTION}

Once hailed as the most useful pesticide ever developed, the benefits and risks of DDT $[1,1,1$-trichloro-2,2-bis (p-chlorophenyl) ethane] in the global ecosystem are now being questioned. Annual production of DDT in the United States rose from 3.5 million kilograms in 1946 to a maximum of 81.3 million kilograms in 1963 (Butler, 1971; Woodwel1, Craig, and Johnson, 1971). Early workers (e.g., Sandholzer, 1945) did not notice any adverse effects on aquatic organisms. The inherent dangers of DDT were recognized by Cottam and Higgins (1946). They proposed close scrutiny and regulation of its use. Numerous studies have since documented the physiological and biochemical effects of DDT for a variety of organisms (see reviews by Johnson, 1968; Cope, 1971; Walsh, 1972). The Environmental Protection Agency has removed DDT from most domestic usage as of 1 January 1973 because of this research.

DDT residues (DDT, DDD, and DDE) have been found in most organisms examined, though the concentrations are variable. The ubiquity of DDT residues is chiefly due to: 1) continuing worldwide usage because DDT is inexpensive and quite effective, 2) aeolian dispersal by global winds (Risebrough et al., 1968), 3) accumulation and release of residues by marsh sediments (Woodwell, Wurster, and Isaacson, 1967), and 4) persistance of residues for over 15 years in sediments (Nash and Woolson, 1967). 
toxins. The precise mode of action of DDT on aquatic organisms is still unclear. Nerve transmission interference (O'Brien, 1966), general disruption of cellular functions (Yarbrough and Wells, 1971), and inhibition of fundamental biochenical enzymatic functions (Davis and Wedemeyer, 1971; Hansen, 1972; Hiltibran, 1971; Janicki and Kinter, 1971) have recently been demonstrated.

Organochlorine insecticides act as central nervous system stimulants in crustaceans. Acute exposure results in hyper-irritability, wild swimming, loss of equilibrium, convulsions, and paralysis eventually leading to death (Eisler, 1969; Mahood et al., 1970). Pesticides have been found to delay or inhibit molting and development of the larval crabs Cancer magister, Leptodius floridanus, and Panopeus herbstii (Buchanan, Milleman, and Stewart, 1970; Epifanio, 1971, 1972). Juvenile blue crabs, Callinectes sapidus, are sensitive to low concentrations of water-borne DDT (Lowe, 1965). Shrimp (Palaemonetes vulgaris and Crangon septemspinosa) and hermit crabs ( $\underline{\text { Pagurus }}$ longicarpus) have a 96 hour TL50 of between 0.6 and $6.0 \mathrm{ppb}$ DDT (Eisler, 1969). Exposure to 1 ppm DDT for 24 hours kills adult blue crabs (Mahood et al., 1970). Biological concentration factors of 1.1 to $10 \times 10^{3}$ have been reported for crustaceans (Cox, 1971; Johnson et al., 1971). Localization of DDT in specific tissues of invertebrates is poorly known. Fiddler crabs (Uca pugnax) accumulated three times more DDT in the muscle of the large claw when fed a DDT-contaminated diet than did controls (Odun, Woodwell, and Wurster, 1969). The hepatopancreas, heart, gills, and tail muscle of pink and white shrimp ( $\underline{\text { Penaeus }}$ duorarum and $\underline{\mathrm{P}}$. setiferus) accumulated 
significant amounts of DDT during a chronic exposure to this pesticide (Nimmo, Wilson, and Blackman, 1970).

The blue crab, Callinectes sapidus, of the Atlantic and Gulf Coasts of the United States supports one of the most valuable fisheries in the nation. Total yearly catch of blue crabs in the Chesapeake and South Atlantic regions of the U.S. usually exceeds all other fish and shellfish except menhaden (Tagatz, 1965; National Marine Fisheries Service, 1972). The effects and body burden of persistant organochlorine pesticides in blue crabs is thus important from biological, economic, and public health standpoints .

The present study documents and examines the accumulation and biotransformation of water-borne DDT by the gills, hepatopancreas, gonads, heart, claw, and backfin muscles of adult blue crabs. Specific aspects investigated were: 1) present DDT, DDD, and DDE residue levels in these organs, 2) accunulation of DDT in body organs of blue crabs following acute exposure to DDT, 3) DDT, DDD, and DDE transfer between organs through time, and 4) rates of metabolism and loss of DDT and its metabolites from blue crab organs . 


\section{MATERIALS AND METHODS}

Dosing, Maintenance, and Sampling

Each DDT exposure was conducted in filtered $(10 \mu)$, aerated York River water adjusted to $15 \%$ salinity and $20.5^{\circ} \mathrm{C}$, thus ruling out possible effects of salinity and temperature changes on waterlipid partitioning of DDT (Murphy, 1970; Mahood et al., 1970; Cox, 1971). Exposure tanks were covered, 75 liter plastic pools. Adult blue crabs were collected by dip net from the York River near the Virginia Institute of Marine Science, Gloucester Point, Virginia. Only intemolt males and terminal intermolt females $\left(\mathrm{C}_{4}\right.$ and $\mathrm{C}_{4} \mathrm{~T}$, respectively, of Passano, 1960) of similar sizes were used. Carapace widths ranged from 120 to $167 \mathrm{~mm}$. All test crabs had their full compliment of limbs. All were acclimated to $15 \%$ and $20.5^{\circ} \mathrm{C}$ for at least 48 hours before exposure to DDT.

A series of three concentrations of DDT and one control was used. Technical DDT dissolved in $10 \mathrm{ml}$ acetone was introduced via pipet beneath the surface of the water in amounts calculated to yield $0.01,0.1$, and $1.0 \mathrm{ppm}$ DDT. The control population received $10 \mathrm{ml}$ acetone. Each test population consisted of 20 male and 20 female crabs, although only 8 males and 8 females from each test were analysed. The crabs were held in the exposure tanks for 12 hours following DDT application then removed to wooden cages floating just beneath the surface of the York River near VIMS. Four cages (each $100 \times 50 \times 25 \mathrm{~cm}$ ) were employed. Each cage was 
divided into 10 compartments pernitting free water flow yet preventing cannibalism. Each crab was fed one juvenile fish (Leiostomus xanthurus, average $61 \mathrm{~mm}$ FL) daily.

Two males and two females were taken for analysis from each population at the following intervals: 0 hours (just prior to DDT application), 12, 96, and 240 hours after DDT application except after exposure to $1.0 \mathrm{ppm}$ DDT where the schedule was 0, 12, 144, and 240 hours. Carapace width was measured, and the following organs were resected from each crab and placed in separate glass vials: gill, hepatopancreas, gonad, heart, claw and backfin muscles. The developmental condition of the gonads, as described by Hard (1942) and Pyle and Cronin (1950), was noted. Samples were then weighed and frozen until analysis.

Pesticide Analysis

Residue analysis was conducted according to the method of Wilson (1968). Similar tissues from the four crabs sampled on a given date were pooled and ground with 75 - 90 grams of desiccant ( $90 \%$ anhydrous sodium sulfate : $10 \%$ microfine silica). The dried samples were refrozen, ground once more, then extracted with 250 ml petroleum ether in a Sohxlet apparatus for four hours. Extracts were concentrated on a rotary evaporator and partitioned with acetonitrile. Acetonitrile portions were then concentrated and cleaned on activated Florisil (100-200 mesh) columns. DDT fractions were eluted from the columns with $200 \mathrm{ml} 6 \%$ ethyl ether in petroleum ether. Samples were condensed to $10-25 \mathrm{ml}$, and $3-5 \lambda$ of these extracts were injected into the chromatograph. 
Pesticide analyses were performed with a Varian Aerograph Model 600D gas chromatograph equipped with a tritiun-foil electron capture detector. The column in the chromatograph was packed with 3\% DC-200 on Varaport 30 (80-100 mesh). Operating temperatures were: oven and detector, $190^{\circ} \mathrm{C}$; injector, $210^{\circ} \mathrm{C}$. The carrier gas was ultra-pure nitrogen flowing at approximately $50 \mathrm{ml}$ per minute. Results are uncorrected for per cent recovery. Actual recoveries from a "spiked" muscle sample were: DDT, 97\%; DDD, 89\%; DDE, 90\%. 


\section{RESULTS}

Presence of the metabolites of DDT, but not DDT itself, in most organs of Callinectes sapidus indicates the lack of recent DDT input into the York River, Virginia (Table 1). Total DDT residues have been corrected for interference by polychlorinated biphenyls $(\mathrm{PCB})$. $\mathrm{DDD}$ and $\mathrm{DDE}$ concentrations were highest in the hepatopancreas and below the limit of detection in heart muscle.

Equivalent mortalities occurred in the control population ( 2 males, 2 females), the 0.01 ppm DDT population ( 2 males, 1 female), and the $1.0 \mathrm{ppm}$ DDT population ( 2 males, 2 females). The population exposed to 0.1 ppm DDT expierienced heavy mortality ( 8 males, 3 females). Lower mortality in the $1.0 \mathrm{ppm}$ DDT population tends to rule out DDT as the critical factor for the higher mortality in the $0.1 \mathrm{ppm}$ DDT treatment.

Residue data obtained before and after blue crabs were exposed to various concentrations of DDT in water for 12 hours demonstrate relatively rapid uptake and distribution of DDT by the crabs, as well as rapid biotransformation of DDT to DDD and DDE (Tables 2-4, Figures 1-3). Rates of loss of DDT and other metabolites were inconsistent among the three test concentrations as well as within the organs themselves.

Response of the crabs (measured as uptake and retention) to DDT concentrations of $0.01,0.1$, and $1.0 \mathrm{ppm}$ DDT varied among the organs (Tables 2-4) and suggests DDT transport from the gills to 
TABLE 1

DDT, DDD, and DDE residues observed in blue crab organs from the control population. Residues are expressed in parts per billion $(\mathrm{ppb})$. A dash $(-)$ indicates not detected.

\begin{tabular}{|c|c|c|c|c|c|}
\hline \multirow{2}{*}{ Organ } & \multirow[b]{2}{*}{ Residue } & \multicolumn{4}{|c|}{ Time in hours } \\
\hline & & 0 & 12 & 96 & 240 \\
\hline & DDT & - & - & - & - \\
\hline \multirow{3}{*}{ Gills } & DDD & - & - & - & - \\
\hline & DDE & 6 & 8 & 12 & 8 \\
\hline & $\mathrm{DDT}$ & - & - & - & - \\
\hline \multirow[t]{3}{*}{ Hepatopancreas } & $\mathrm{DDD}$ & 38 & 66 & 79 & 115 \\
\hline & $\mathrm{DDE}$ & 33 & 57 & 74 & 102 \\
\hline & DDT & - & - & - & - \\
\hline \multirow{3}{*}{ Ovaries + Testes } & $\mathrm{DDD}$ & 21 & - & - & 38 \\
\hline & $\mathrm{DDE}$ & 17 & 13 & 9 & 29 \\
\hline & $\mathrm{DDT}$ & - & - & - & - \\
\hline \multirow[t]{3}{*}{ Claw muscle } & DDD & - & - & - & - \\
\hline & $\mathrm{DDE}$ & 8 & - & 13 & 6 \\
\hline & DDT & - & - & - & - \\
\hline \multirow[t]{3}{*}{ Backfin muscle } & $\mathrm{DDD}$ & - & - & - & 5 \\
\hline & DDE & 6 & 6 & 6 & 4 \\
\hline & DDT & - & - & - & - \\
\hline \multirow[t]{2}{*}{ Heart } & DDD & - & - & - & - \\
\hline & $\mathrm{DDE}$ & - & - & - & - \\
\hline
\end{tabular}




\section{TABLE 2}

DDT, DDD, and DDE residues observed in blue crab organs after 12 hour exposure to $0.01 \mathrm{ppm}$ DDT in water. Exposure begins at time 0 . Residues are expressed in parts per billion (ppb). A dash (-) indicates not detected.

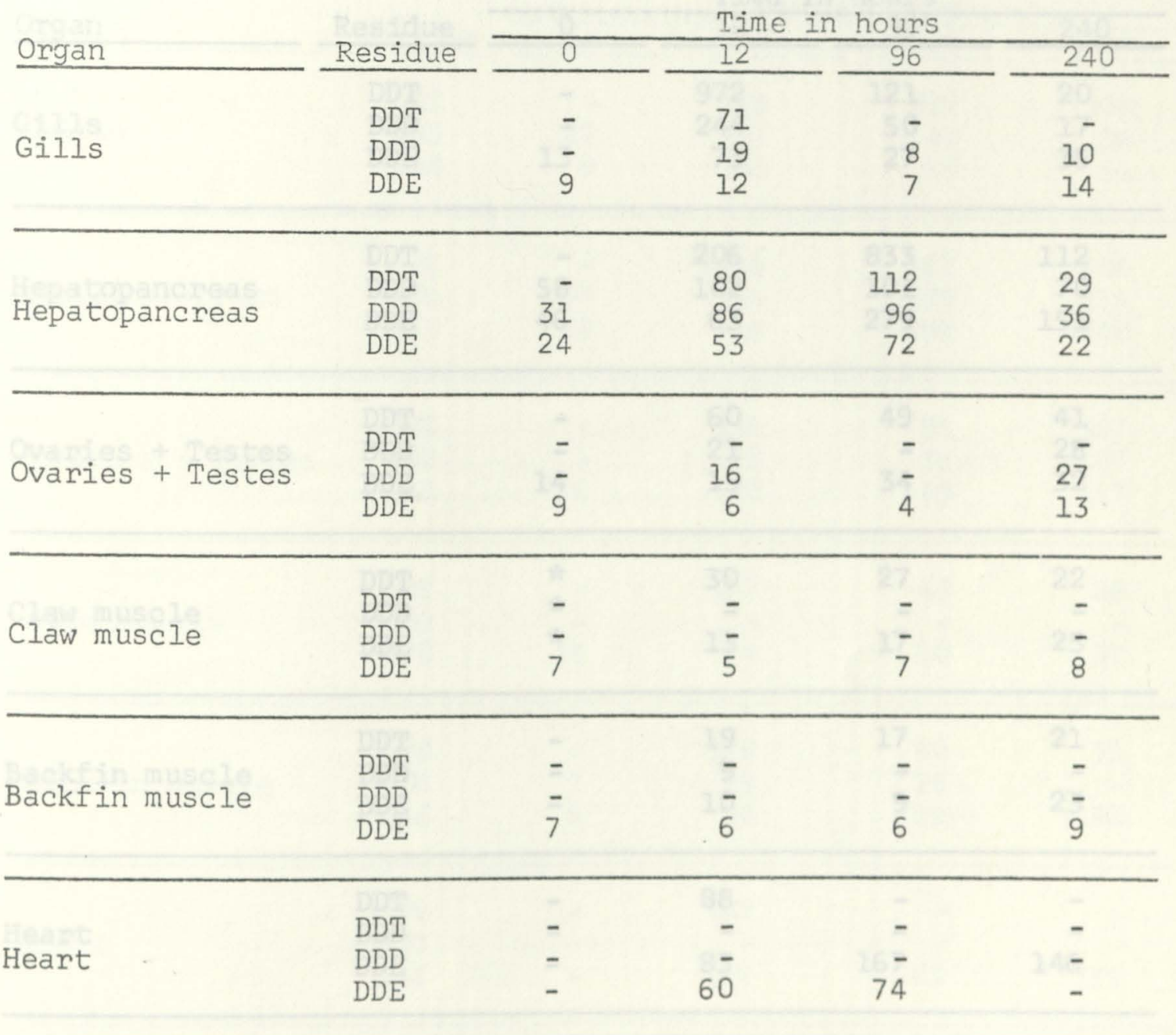


TABLE 3

DDT, DDD, and DDE residues observed in blue crab organs after 12 hour exposure to $0.1 \mathrm{ppm}$ DDT in water. Exposure begins at time 0 . Residues are expressed in parts per billion (ppb). A dash ( $(-)$ indicates not detected. An asterisk (*) indicates sample lost.

\begin{tabular}{|c|c|c|c|c|c|}
\hline \multirow[b]{2}{*}{ Organ } & \multirow[b]{2}{*}{ Residue } & \multicolumn{4}{|c|}{ Time in hours } \\
\hline & & 0 & 12 & 96 & 240 \\
\hline Gills & $\begin{array}{l}\text { DDT } \\
\text { DDD } \\
\text { DDE }\end{array}$ & $\overline{1}$ & $\begin{array}{r}972 \\
244 \\
73\end{array}$ & $\begin{array}{r}121 \\
50 \\
27\end{array}$ & $\begin{array}{l}20 \\
17 \\
35\end{array}$ \\
\hline
\end{tabular}

\begin{tabular}{llrrrr}
\hline & DDT & - & 206 & 833 & 112 \\
Hepatopancreas & DDD & 58 & 102 & 301 & 70 \\
& DDE & 46 & 63 & 279 & 151
\end{tabular}

\begin{tabular}{lccccc}
\hline \multirow{4}{*}{ Ovaries + Testes } & DDT & - & 60 & 49 & 41 \\
& DDD & - & 21 & - & 28 \\
& DDE & 14 & 19 & 34 & 32 \\
\hline \multirow{4}{*}{ Claw muscle } & DDT & $*$ & 30 & 27 & 22 \\
& DDD & $*$ & - & - & - \\
& DDE & $*$ & 13 & 17 & 25 \\
\hline \multirow{3}{*}{ Backfin muscle } & DDT & - & 19 & 17 & 21 \\
& DDD & - & 9 & - & - \\
& DDE & - & 10 & 9 & 23 \\
\hline \multirow{5}{*}{ Heart } & DDT & - & 88 & - & - \\
& DDD & - & - & - & - \\
& DDE & - & 83 & $16 \overline{7}$ & $14 \overline{6}$ \\
\hline
\end{tabular}




\section{TABLE 4}

DDT, DDD, and DDE residues observed in blue crab organs after 12 hour exposure to $1.0 \mathrm{ppm}$ DDT in water. Exposure begins at time 0 . Residues are expressed in parts per billion (ppb). A dash (-) indicates not detected.

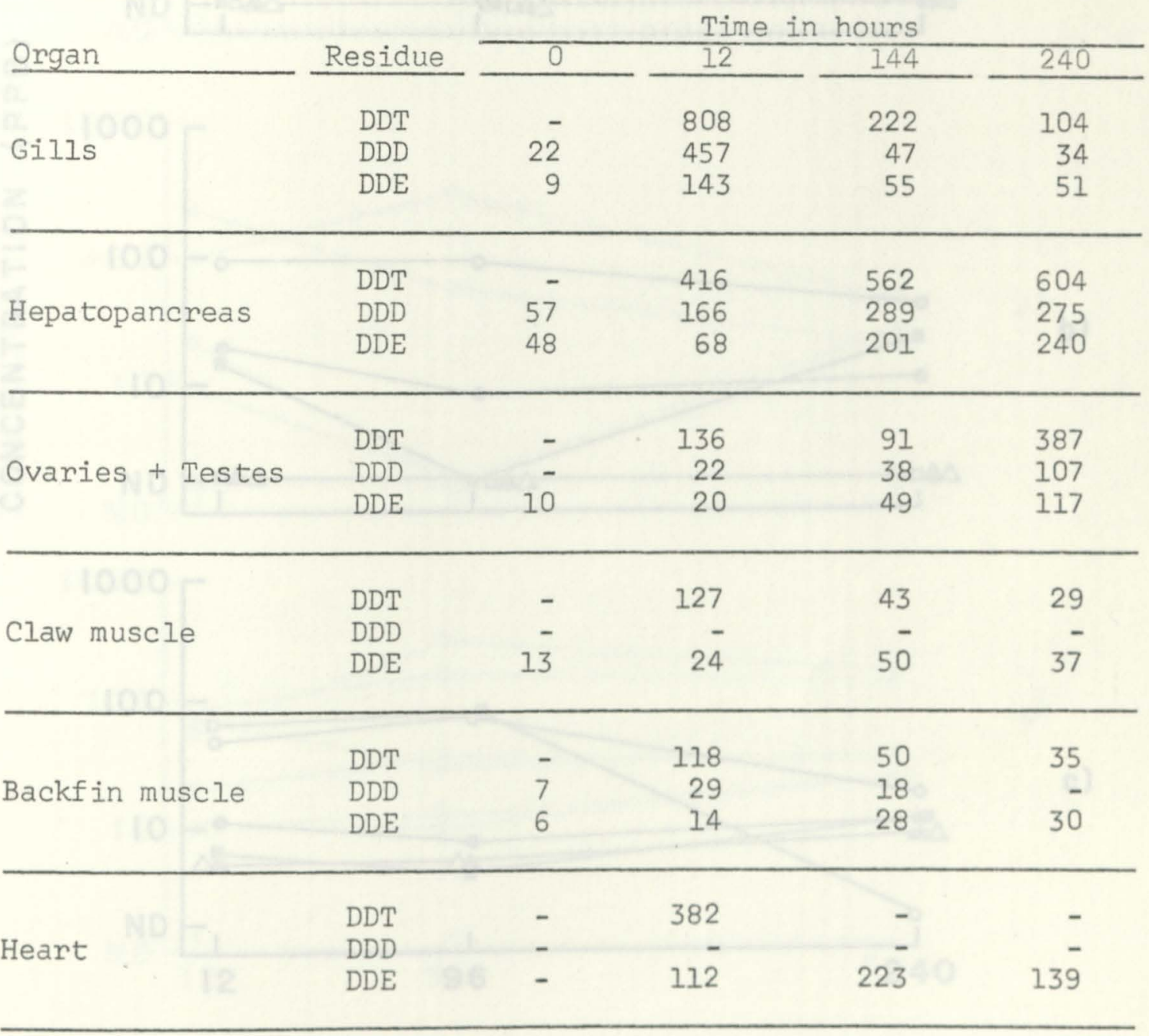




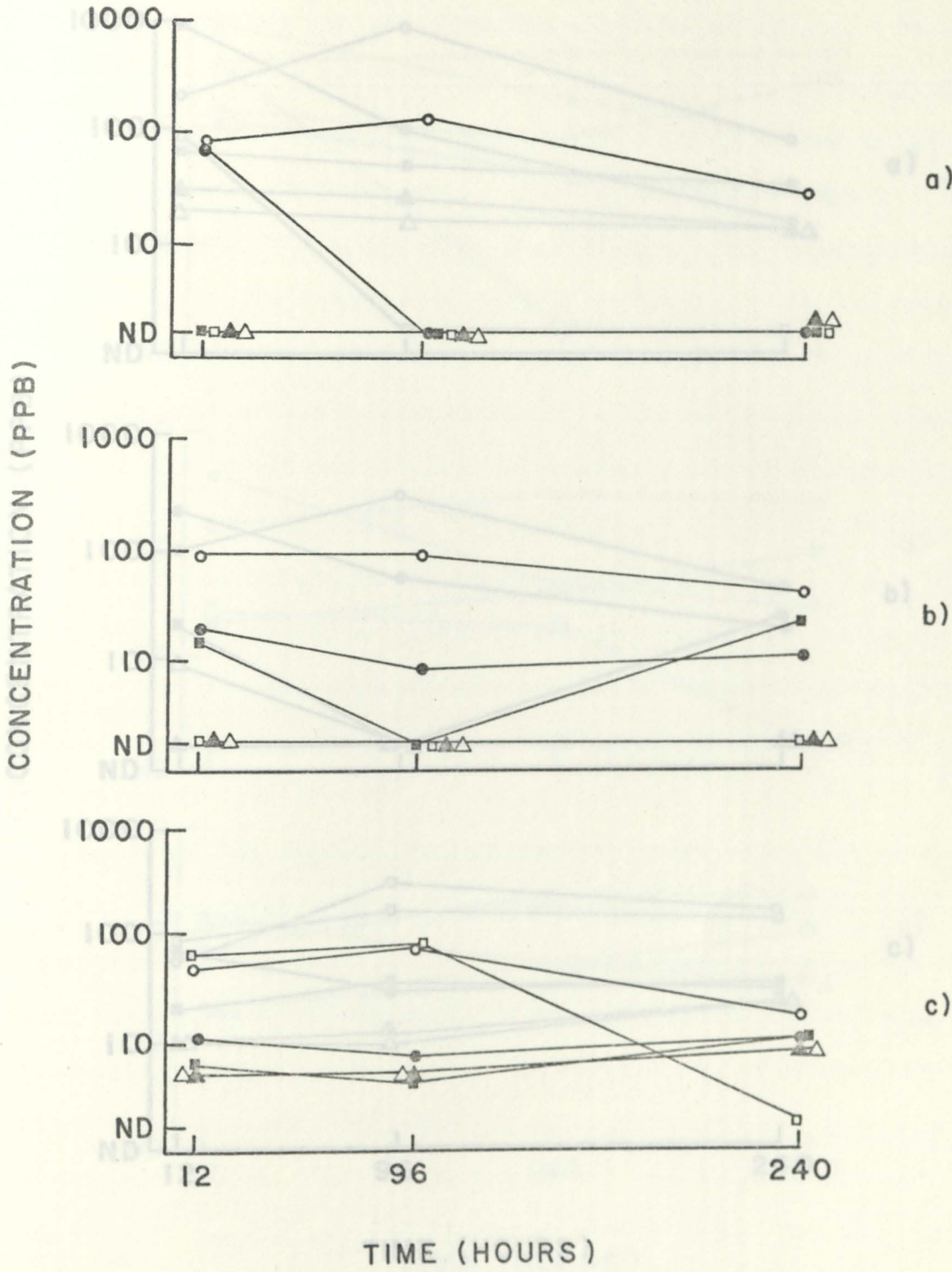

Figure 1. DDT, DDD, and DDE residues observed in blue crab organs following a 12 hour exposure to $0.01 \mathrm{ppm}$ DDT. a) DDT, b) DDD, c) DDE. Residues are expressed in parts per billion ( $\mathrm{ppb})$. Exposure begins at time 0 . Organs examined were: gills $(\bullet)$, hepatopancreas $(\mathbf{0})$, gonads $(\mathbf{0})$, heart $(\boldsymbol{\square})$, claw muscle $(\boldsymbol{\Delta})$, and backfin muscle $(\boldsymbol{\Delta})$. 


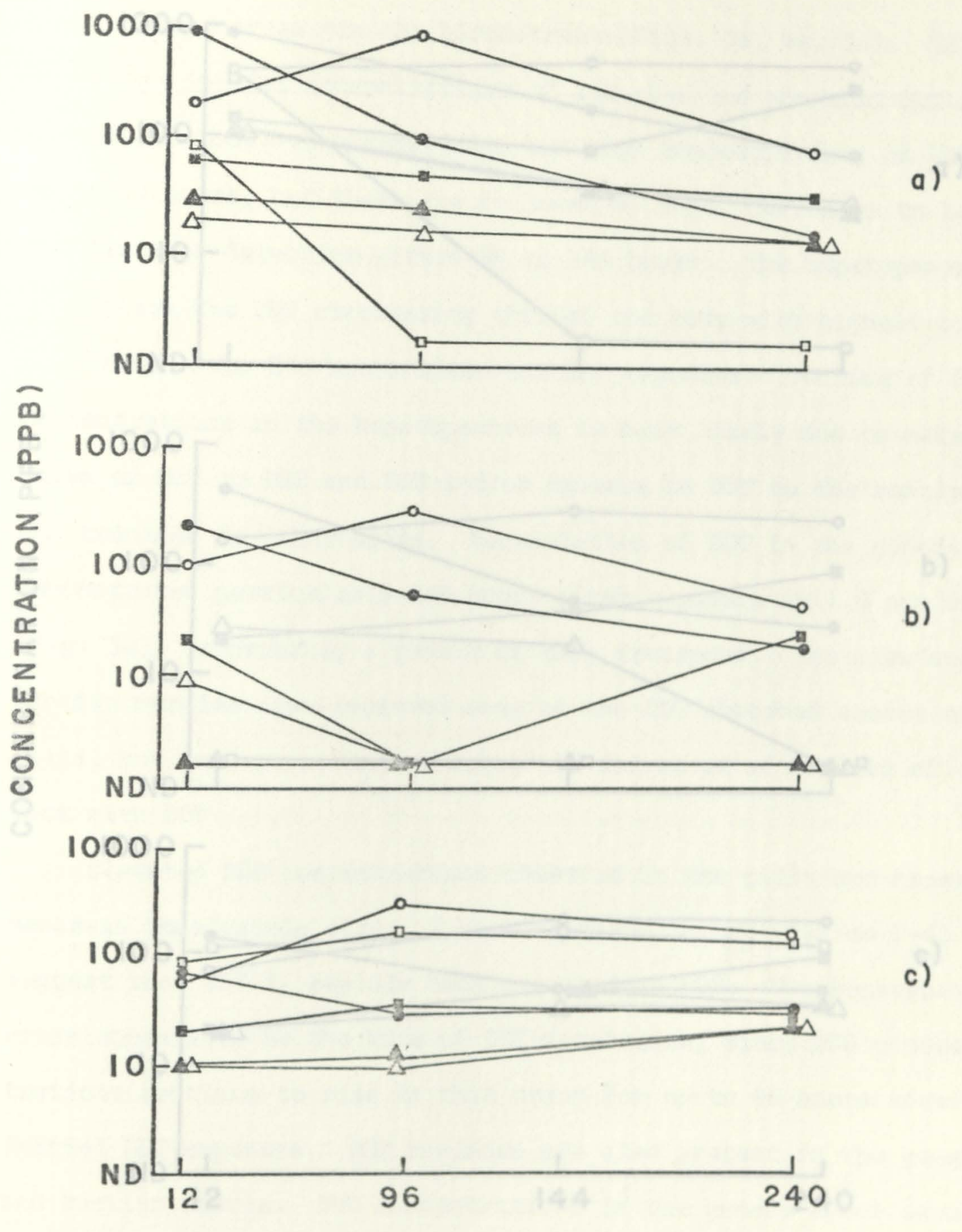

TIME (HOURS)

Figure 2. DDT, DDD, and DDE residues observed in blue crab organs following a 12 hour exposure to $0.1 \mathrm{ppm}$ DDT. a) DDT, b) DDD, c) DDE. Residues are expressed in parts per billion (ppb). Exposure begins at time 0 . Organs examined were: gills $(\bullet)$, hepatopancreas $(\mathbf{0})$, gonads $(\mathbf{0})$, heart ( $\boldsymbol{a})$, claw muscle $(\boldsymbol{\Delta})$, and backf in muscle $(\Delta)$. 


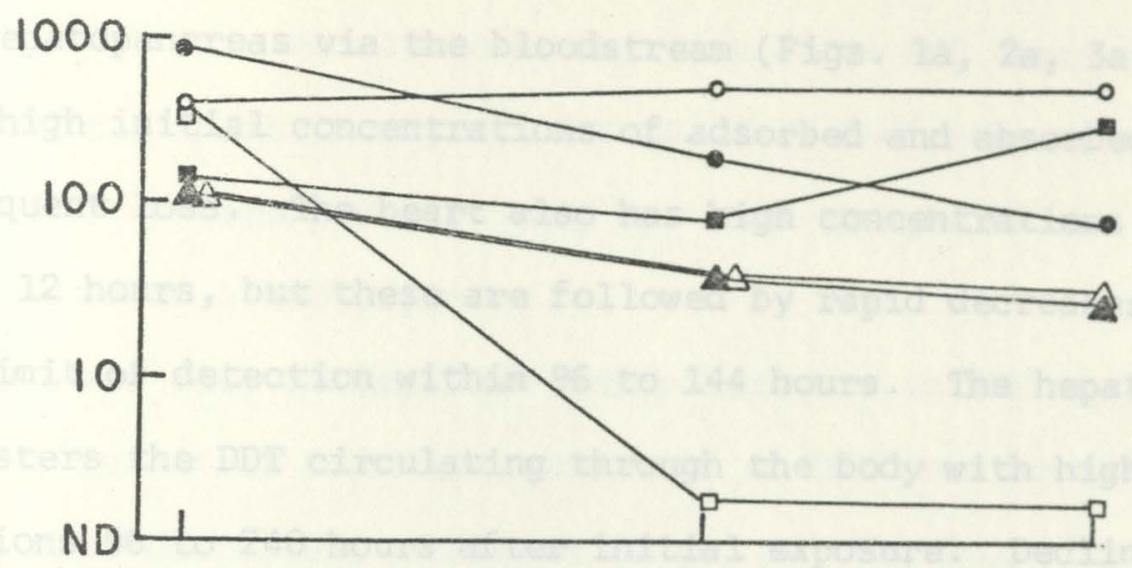

a)

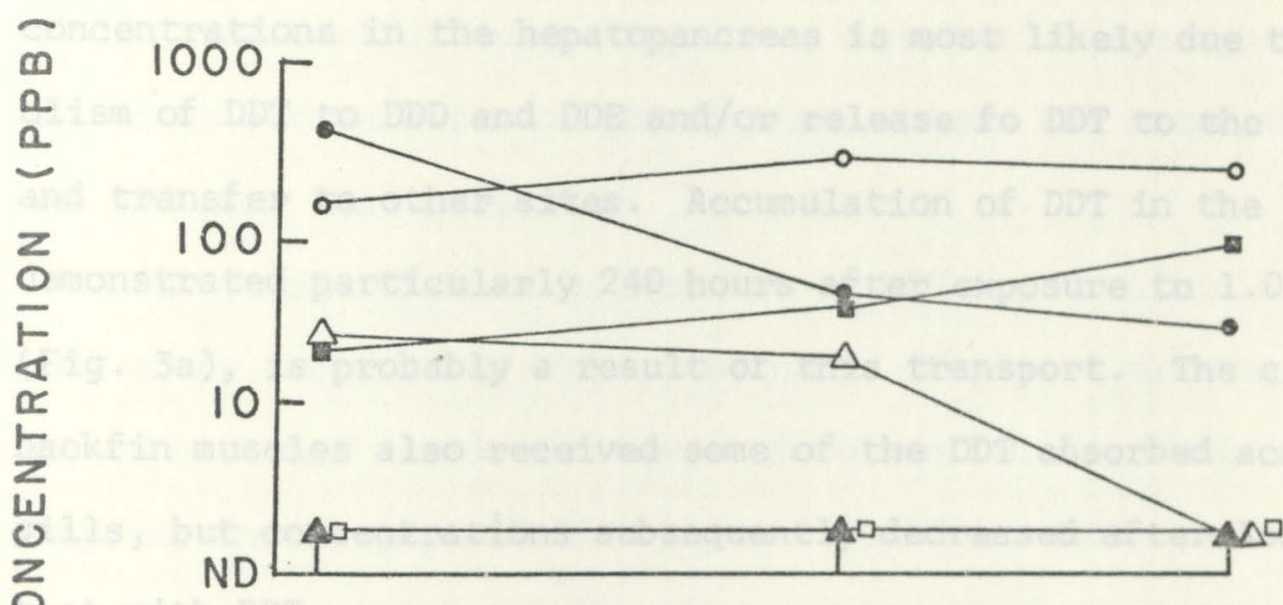

b)

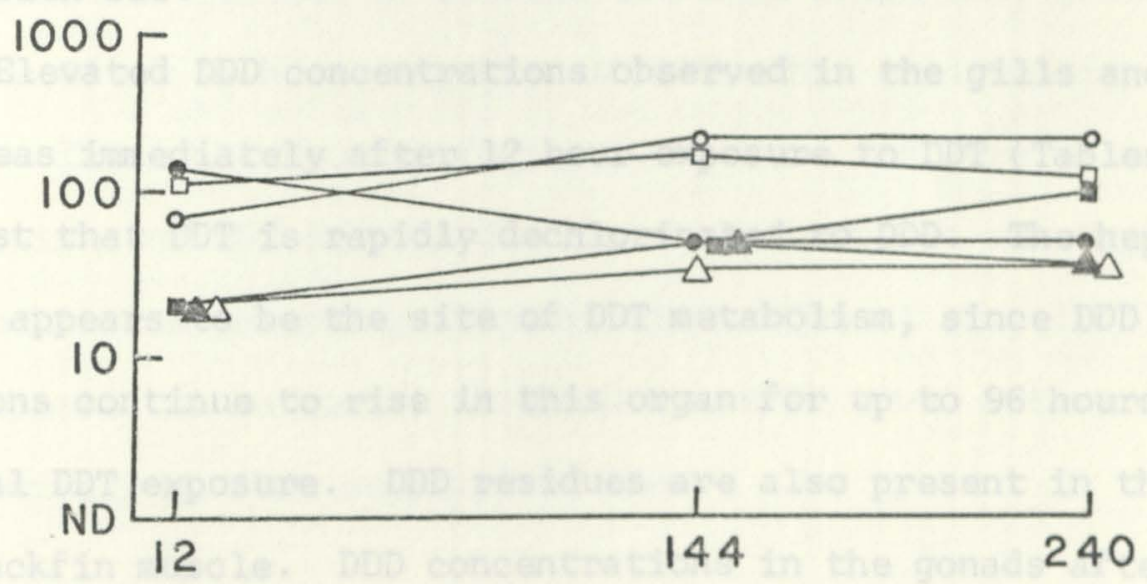

c)

\section{TIME (HOURS)}

Figure 3. DDT, DDD, and DDE residues observed in blue crab organs following a 12 hour exposure to $1.0 \mathrm{ppm}$ DDT. a) DDT, b) DDD, c) DDE. Residues are expressed in parts per billion (ppb). Exposure begins at time 0. Organs examined were: gills (0), hepatopancreas (0), gonads ( $\mathbf{0})$, heart ( $(\boldsymbol{\sigma})$, claw muscle $(\boldsymbol{\Delta})$, and backf in muscle $(\boldsymbol{\Delta})$. 
the hepatopancreas via the bloodstream (Figs. 1a, 2a, 3a). Gills show high initial concentrations of adsorbed and absorbed DDT with subsequent loss. The heart also has high concentrations of DDT after 12 hours, but these are followed by rapid decreases to below the limit of detection within 96 to 144 hours. The hepatopancreas sequesters the DDT circulating through the body with highest accumulations 96 to 240 hours after initial exposure. Decline of DDT concentrations in the hepatopancreas is most likely due to metabolism of DDT to DDD and DDE and/or release fo DDT to the hemolymph and transfer to other sites. Accumulation of DDT in the gonads, demonstrated particularly 240 hours after exposure to $1.0 \mathrm{ppm}$ DDT (Fig. 3a), is probably a result of this transport. The claw and backfin muscles also received some of the DDT absorbed across the gills, but concentrations subsequently decreased after loss of contact with DDT.

Elevated DDD concentrations observed in the gills and hepatopancreas inmediately after 12 hour exposure to DDT (Tables 2-4) suggest that DDT is rapidly dechlorinated to DDD. The hepatopancreas appears to be the site of DDT metabolism, since DDD concentrations continue to rise in this organ for up to 96 hours after initial DDT exposure. DDD residues are also present in the gonads and backfin muscle. DDD concentrations in the gonads after exposure to 0.01 and $0.1 \mathrm{ppm}$ DDT fluctuate widely (Figs. 1b, 2b), yet this fluctuation is not visible in reaction to $1.0 \mathrm{ppm}$ DDT (Fig. 3b). The wide range of DDD concentrations in the gonads of controls (ND-38 ppb) (Table 1 ) and the developmental condition of the gonads undoubtedly contribute to these observations. No DDD was detected 
in the heart or claw muscle at any time after DDT exposure, nor was DDD detected in these organs of controls. Instantaneous hemolymph levels of DDD were probably very low even though DDD was rapidly distributed to other organs.

DDT was also metabolised either directly to DDE or through DDD to DDE. Immediate high concentrations of DDE were seen in the gills, hepatopancreas, and heart (Figs. 1c, 2c, 3c). Gonads, claw muscle, and backfin muscle appear to function as storage sites for DDE since accunulation of DDE in these organs was noted throughout the 240 hour test periods.

Behavioral changes in response to DDT began within a short time after exposure to DDT. Test crabs displayed extreme sensitivity to external sounds and movement, of ten raising their claws and snapping in the general direction of the disturbance. The response also included periods of frantic swimming which only gradually subsided. After 12 hours exposure to DDT, this excitability was reduced. The crabs became progressively more listless as test concentrations of DDT increased. These observations are typical of organochlorine poisoning (Eisler, 1969; Odum et al., 1969). Activity appeared to be normal after 12 hours in river water, and crabs fed actively on fish supplied to them. 


\section{DISCUSSION}

Entry of DDT into an aquatic organism like Callinectes sapidus must be a two phase process since lipid components of the organism are not in direct contact with the environment. DDT molecules must first be adsorbed to the surfaces in contact with the water, then absorbed into Iipid components of the crab's system by diffusion or active transport. However, uptake of adsorbed DDT is to some extent reversible when the organism is removed from the test solution to a control environment in that there is rapid loss of DDT from the gills but continued accumulation in the hepatopancreas after the crabs are removed from the source of DDT (Figs. 1a, 2a, 3a). Loss of DDT from the gills is probably a combination of transport into serum lipids and washing off by the respiratory mechanism and water current. Gastrointestinal uptake is a possible entry route for water-borne pesticides but it is probable that more pesticide is contacted by the gills while pumping than by the gut while feeding (Epifanio, 1972).

High concentrations of DDT in the gills are probably a result of adsorbed pesticide molecules. However, immediate accumulation of high concentrations of $\mathrm{DDD}$ and $\mathrm{DDE}$ in the gills is a puzzle. These residues may indicate concentrations in the hemolymph. If so, DDD would have been detected in the heart samples, an event that was not observed even though heart samples contained some associated serum. There may be sites on the inner surfaces of the gills which 
remove residues from the hemolymph as it circulates through the gills. My methods do not allow conclusions about this possibility. The hepatopancreas of the blue crab is the likely site of biotransformation of DDT and storage of residues since it functions to secrete digestive enzymes and to absorb and store nutrients (Vonk, 1960). The highest concentrations of DDT, DDD, and DDE were found in the hepatopancreas with the exception of the gills immediately after DDT exposure (Tables $2-4$ ).

Once in contact with the organism, DDT and its metabolites is more readily soluble in lipids than in other components due to its molecular polarity. DDT will bind with phospholipids because of its electron structure (Tinsley, Hague, and Schmedding, 1971; Wilson and Wilson, 1972). Lipid levels in blue crab organs have not been documented, though data are available for other species of decapod crustaceans. Pillay and Nair (1973) determined the following for three species of decapods (Uca annulipes, Portunus pelagicus and Metapenaeus affinis): 1) the relative lipid richness of various organs is hepatopancreas / gonads, muscle, 2) ovaries contain more lipid than testes, 3) ovary lipid content increases with maturation, and 4) lipids are mobilized from the hepatopancreas to the ovaries when oocytes are developing. My analyses for the control population (Table 1) show total DDT residues greatest in the hepatopancreas, intermediate in the gonads, and lowest in muscle.

The effects of pesticide residues in gonads of blue crabs on the success of hatching and development of juvenile crabs is the most important aspect of pesticide pollution. Development of the gonads includes transfer of lipids from the hepatopancreas to the 
ovaries and, to a lesser extent, to the testes (Pillay and Nair, 1973). Reproductive condition of blue crabs used in this study was noted before pesticide analysis (Table 5). Comparison of the developmental stages of the gonads of unexposed crabs with the residues contained in them (Tables 1-4) indicates that the stage of development of the ovaries is the factor controlling the incidence and amounts of DDD and DDE in the ovaries. Samples consisting of immature ovaries plus either immature or mature testes contained only DDE. Samples with developing or mature ovaries contained both $\mathrm{DDD}$ and DDE. It appears that DDD (and DDE) is transferred along with lipids from the hepatopancreas to developing ovaries. Only crabs with developing or mature ovaries contained DDD after exposure to DDT, with the exception of the 144 hour sample after exposure to $1.0 \mathrm{ppm}$ DDT. The accumulation of DDT and other metabolites in the gonads of blue crabs poses a threat to the success of oogenesis and spermatogenesis and to the viability of fertilized eggs. The detrimental effects of minute amounts of chlorinated hydrocarbons on larval and juvenile crabs (Callinectes sapidus, Leptodius floridanus, and Panopeus herbstii) have been shown by Lowe (1965) and Epifanio (1971).

DDE concentrations in the claw and backfin muscles of blue crabs increase with time after exposure to DDT (Figs. 1c, 2c, 3c). These organs are low in lipid content but are relatively high in protein (Pillay and Nair, 1973). DDT can be bound to polar aromatic constituents of proteins (Wilson and Wilson, 1972). Although lipid binding is energetically more favorable in terms of enthalpy and free energy changes, lipid sites may be unavailable and protein 


\section{TABLE 5}

Reproductive condition of control and DDT-exposed blue crabs. Ovarian development was noted by: I - ovaries small and white, seminal receptacles enlarged; II - ovaries developing and orange; III - ovaries mature and bright orange. Testicular development was noted by: I - testes small and inmature, median vas deferens small and white; II-testes well developed, median vas deferens large and bright pink. Each sample consisted of pooling the two male and two female crabs sampled on a given date, except where noted by $(*)$. Time refers to hours after DDT exposure.

\begin{tabular}{|c|c|c|c|c|c|}
\hline Exposure & Sex & 0 & 12 & 96 & 240 \\
\hline Control & $\begin{array}{l}0^{\prime \prime} \\
q\end{array}$ & $\begin{array}{c}I, I \\
I I, I I\end{array}$ & $\begin{array}{l}I, I \\
I, I\end{array}$ & $\begin{array}{c}I I, I I \\
I, I\end{array}$ & $\begin{array}{l}I I, I I \\
I I, I I I\end{array}$ \\
\hline $0.01 \mathrm{ppm}$ DDT & $\begin{array}{l}0^{*} \\
q\end{array}$ & $\begin{array}{l}I, I I \\
I, I\end{array}$ & $\begin{array}{l}*, \text { II } \\
\text { I, III }\end{array}$ & $\begin{array}{l}I I, I I \\
I, I I\end{array}$ & $\begin{array}{c}I, I \\
\text { III,III }\end{array}$ \\
\hline $0.1 \mathrm{ppm} \mathrm{DDT}$ & $\begin{array}{l}\sigma^{*} \\
q\end{array}$ & $\begin{array}{c}\text { II,II } \\
I, I\end{array}$ & $\begin{array}{l}I I, I I \\
I I, I I I\end{array}$ & $\begin{array}{l}*, I \\
*, I\end{array}$ & $\stackrel{*, I I}{I, I I}$ \\
\hline $1.0 \mathrm{ppm}$ DDT & $\begin{array}{l}\sigma^{\prime \prime} \\
q\end{array}$ & $\begin{array}{l}I, I I \\
I, I\end{array}$ & $\begin{array}{l}I I, I I \\
I, I I\end{array}$ & $\begin{array}{l}I, I I \\
I, I\end{array}$ & $\begin{array}{l}*, \text { I } \\
* \text {, III }\end{array}$ \\
\hline
\end{tabular}


binding of DDT residues could occur in blue crab muscle.

This study revealed accumulation of DDT, DDD, and DDE in major organs of Callinectes sapidus. Compilation of residue data reported for other marine crustaceans (Table 6) and its comparison with my data (Table 7) indicates that blue crabs in the York River, Virginia, have somewhat lower total DDT residue levels relative to other crustaceans. Blue crabs from the South Atlantic states (Mahood et al., 1970) have a greater range of total DDT residues than I found, and they have relatively high concentrations of DDT itself. Moore (1971) found significant uptake and deposition of fluoride ion in the hepatopancreas, gills, and backfin muscle of the blue crab. Odun et al. (1969) noted that DDT accumulated in the muscle of the large claw of Uca pugnax when fed a DDT-contaminated diet. The claw muscle in blue crabs is not a major storage site of DDT residues, yet it did accumulate DDT and DDE above control levels. Transfer of DDT and its metabolites between the gills and the hepatopancreas in the blue crab corresponds with data presented by Nimmo et al. (1970) for Penaeus duorarum and Penaeus setiferous.

In conclusion, presence of metabolites of DDT in the major organs of the blue crab, Callinectes sapidus, has been docunented. Organs of the blue crab accumulate significant amounts of DDT during acute exposure. Gills were the major site of uptake of waterborne DDT. Biotransformation and distribution of DDT and its breakdown products were controlled by the hepatopancreas. Induction of metabolic transformation of DDT to DDD and DDE was immediate, but the rate of metabolism of DDT could not be calculated due to 
TABLE 6 Reported DDT, DDD, DDE, and total DDT ( $\mathrm{DDT}$ ) in selected marine crustaceans. Residues are expressed in parts per billion (ppb).

Reference + Area

Mahood et al., 1970

South Atlantic United States

Species

Callinectes sapidus

Sample

DDT DDD soft tissue

-

Robinson et a1., 1967 Northumberland Coast, United Kingdom

西

Earnest + Benville, 1971

w San Francisco Bay

$\begin{array}{ll}\frac{\text { Carcinus }}{\text { maenus }} & \text { whole } \\ \frac{\text { Carcinus }}{\text { pagurus }} & \text { whole }\end{array}$

$\frac{\text { Cancer }}{\text { magister }}$

Modin, 1969

California

$\frac{\text { Cancer }}{\text { magister }}$

Aucamp et al., 1971

South Africa

$\frac{\text { Jasus }}{\text { lalandii }}$

whole

$\frac{\mathrm{DDT}}{86} \frac{\mathrm{DDD}}{\begin{array}{c}73 \\ (12-247)\end{array}(9-188)} \frac{\mathrm{DDE}}{(10-231)} \frac{\text { EDDT }}{\begin{array}{c}64 \\ (34-517)\end{array}}$

\begin{tabular}{l}
24 \\
-79 \\
\hline
\end{tabular}

Munson, 1972
California

$\frac{\text { Panulirus }}{\text { interruptus }} \quad$ muscle

Sprague + Duffy, 1971
New Brunswick, Canada

$\frac{\text { Homarus }}{\text { americanus }}$

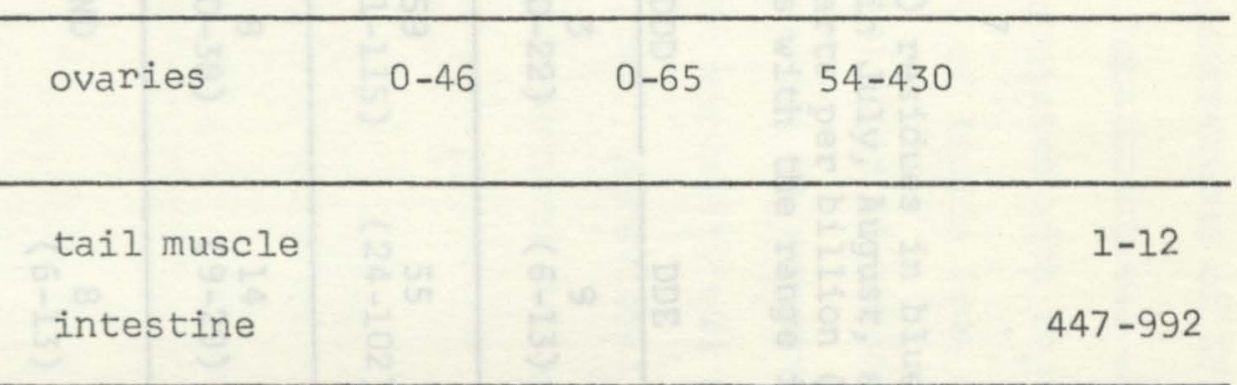

\begin{tabular}{llll}
\hline tail muscle & 10 & 10 & 30 \\
ovaries & 40 & 10 & 310
\end{tabular}




\section{TABLE 7}

DDT, DDD, DDE, and total DDT ( $E D D T$ ) residues in blue crabs collected from the York River, Virginia, in July, August, and September, 1972. Residues are expressed in parts per billion ( $\mathrm{ppb}$ ) and data represent the mean of seven samples with the range in parentheses. ND indicates not detected.

\begin{tabular}{|c|c|c|c|c|}
\hline Organ & $\mathrm{DDT}$ & DDD & DDE & EDDT \\
\hline Gills & ND & $\begin{array}{c}3 \\
(N D-22)\end{array}$ & $\begin{array}{c}9 \\
(6-13)\end{array}$ & $\begin{array}{l}12 \\
(6-31)\end{array}$ \\
\hline
\end{tabular}

\begin{tabular}{lcccc}
\hline Hepatopancreas & ND & $\begin{array}{c}59 \\
(31-115)\end{array}$ & $\begin{array}{c}55 \\
(24-102)\end{array}$ & $\begin{array}{c}114 \\
(55-217)\end{array}$ \\
\hline Ovaries + Testes & ND & $\begin{array}{c}8 \\
(N D-38)\end{array}$ & $\begin{array}{c}14 \\
(9-29)\end{array}$ & $\begin{array}{c}23 \\
(9-67)\end{array}$ \\
\hline Claw muscle & ND & ND & $\begin{array}{c}8 \\
(6-13)\end{array}$ & $\begin{array}{c}8 \\
(6-13)\end{array}$ \\
\hline Backfin muscle & ND & $\begin{array}{c}2 \\
(N D-7)\end{array}$ & $\begin{array}{c}5 \\
(N D-7)\end{array}$ & $\begin{array}{c}7 \\
(N D-13)\end{array}$ \\
\hline $\begin{array}{l}\text { Heart } \\
\text { of all organs }\end{array}$ & ND & ND & ND & ND \\
\hline $\begin{array}{l}\text { Combined total } \\
\text { of }\end{array}$ & ND & $(8-30)$ & $\begin{array}{c}17 \\
(12-27)\end{array}$ & $\begin{array}{c}33 \\
(19-57)\end{array}$ \\
\hline
\end{tabular}


differing responses to various concentrations of DDT. Storage of these residues was greatest in the hepatopancreas and gonads. Occurrence of DDD in gonads was associated with reproductive condition of the ovaries and transport of lipids from the hepatopancreas to developing ovaries. Rate of loss of residues from the different organs of the blue crab varied in response to DDT exposure concentrations. No significant mortality was noticed after 12 hour exposures of up to $1.0 \mathrm{ppm}$ DDT. Behavioral alterations typical of organochlorine stress were noticed during all DDT exposures. 


\section{LITERATURE CITED}

Aucamp, P. J., J. L. Henry, and G. H. Stander. 1971. Pesticide residues in South African marine aninals. Mar. Poll. Bull. 2(12): 190-191.

Buchanan, D. V., R. E. Milleman, and N. E. Stewart. 1970. Effects of the insecticide Sevin on various stages of the Dungeness crab, Cancer magister. J. Fish. Res. Bd. Can. 27(1):93-104.

Butler, P. A. 1971. Influence of pesticides on marine ecosystems. Proc. Roy. Soc. London B 177:321-329.

Cope, O. B. 1971. Interactions between pesticides and wildlife. Annual Rev. Entomol. 16:325-364.

Cottam, C. and E. Higgins. 1946. DDT: its effect on fish and wildlife. U. S. Fish and Wildl. Serv., Circular 11. 14p.

Cox, J. L. 1971. Uptake, assimilation, and loss of DDT residues by Euphausia pacifica, a euphausid shrimp. Fishery Bull. 69: $627-633$.

Davis, P. W. and G. A. Wedemeyer. 1971. $\mathrm{Na}^{+}, \mathrm{K}^{+}$- activated ATPase inhibition in rainbow trout: a site for organochlorine pesticide toxicity? Comp. Biochen. Physiol. 40B:823-827.

Earnest, R. D. and P. E. Benville. 1971. Correlation of DDT and lipid levels for certain San Francisco Bay fish. Pestic. Monit. J. 5(3):235-241.

Eisler, R. 1969. Acute toxicities of insecticides to marine decapod crustaceans. Crustaceana 16(Part 3):302-310.

Epifanio, C. E. 1971. Effects of dieldrin in sea water on the development of two species of crab larvae, Leptodius floridanus and Panopeus herbstii. Mar. Biol. 11(4):356-362.

Epifanio, C. E. 1972. Effects of dieldrin-contaminated food on the development of Leptodius floridanus larvae.

Hansen, D. J. 1972. DDT and malathion: effect on salinity selection by mosquitofish. Trans. An. Fish. Soc. 101(2):346-350.

Hard, W. L. 1942. Ovarian growth and ovulation in the mature blue crab, Callinectes sapidus Rathbun. Chesapeake Biol. Lab.

Publ. $46.17 \mathrm{p}$. 
Hiltibran, R. C. 1971. A proposed biochemical mechanism of the toxic action of DDT. Trans. Ill. State Acad. Sci. 64(1):4654 .

Janicki, R. H. and W. B. Kinter. 1971. DDT: disrupted osmoregulatory events in the intestine of the eel Anguilla rostrata adapted to sea water. Science 173(4002): 1 $146-1148$.

Johnson, B. T., C. R. Saunders, H. O. Sanders, and R. S. Campbell. 1971. Biological magnification and degradation of DDT and aldrin by freshwater invertebrates. J. Fish. Res. Bd. Can . 28(5): $705-709$.

Johnson, D. W. 1968. Pesticides and fishes - a review of selected literature. Trans. Am. Fish. Soc. 97(3):398-424.

Lowe, J. I. 1965. Chronic exposure of blue crabs, Callinectes sapidus, to sublethal concentrations of DDT. Ecology 46(6): 899-900.

Mahood, R. K., M. D. McKenzie, D. P. Middaugh, S. J. Bollar, J. R. Davis, and D. Spitzbergen. 1970. A report on the cooperative blue crab study - South Atlantic states. Ga. Game and Fish Comm., Coastal Fish. Div., Contrib. Ser. No. 19. 32p.

Modin, J. C. 1969. Chlorinated hydrocarbon pesticides in California bays and estuaries. Pestic. Monit. J. 3(1):1-7.

Moore, D. J. 1971. The uptake and concentration of fluoride by the blue crab, Callinectes sapidus. Chesapeake Sci. 12(1): $1-13$.

Munson, T. O. 1972. Chlorinated hydrocarbon residues in marine animals of Southern California. Bull. Envir. Contam. Toxicol. $7(4): 223-228$.

Murphy, P. G. 1970. Effects of salinity on uptake of DDT, DDD, and DDE by fish. Bull. Envir. Contam. Toxicol. 5(5):404-407.

Nash, R. G. and E. A. Woolson. 1967. Persistance of chlorinated hydrocarbon insecticides in soils. Science 157(3791):924.

National Marine Fisheries Service. 1972. Fishery statistics of the United States, 1969. Nat. Mar. Fish. Serv. Statistical Digest 63. 474p.

Ninmo, D. R., A. J. Wilson, Jr., and R. R. Blackman. 1970. Localization of DDT in the body organs of pink and white shrimp. Bull. Envir. Contam. Toxicol. 5(4):333-341.

O'Brien, R. D. 1966. Mode of action of insecticides. Annual Rev. Entomol. 1.1: 369-402. 
Odum, W. E., G. M. Woodwell, and C. F. Wurster. 1969. DDT residues absorbed from organic detritus by fiddler crabs. Science $164(3879): 576-578$.

Passano, L. M. 1960. Molting and its control. In T. H. Wateman (ed.), The Fhysiology of Crustacea. Vol. I. Metabolism and growth. Acadernic Press. Inc. New York. pp. 473-536.

Pillay, N. K. and N. B. Nair. 1973. Observations on the biochemical changes in gonads and other organs of Uca annulipes, Portunus pelagicus, and Metapenaeus affinis (Decapoda: Crustacea) during the reproductive cycle. Mar. Biol. 18(3): $167-198$.

Pyle, R. and E. Cronin. 1950. The general anatomy of the blue crab Callinectes sapidus Rathbun. Chesapeake Biol. Lab. Publ. No. $87.40 \mathrm{p}$.

Risebrough, R. W., R. J. Huggett, J. J. Griffin, and E. D. Goldberg. 1968. Pesticides: Trans-Atlantic movement in the Northeast Trades. Science 159(3820):1233-1236.

Robinson, J., A. Richardson, A. N. Crabtree, J. C. Coulson, and G. R. Potts. 1967. Organochlorine residues in marine organisms. Nature 214(5095):1307-1311.

Sandholzer, L. A. 1945. The effect of DDT on the Chesapeake Bay blue crab (Callinectes sapidus). Fishery Mkt. News 7(11):2-4.

Sprague, J. B. and J. R. Duffy. 1971. DDT residues in Canadian Atlantic fishes and shellfishes in 1967. J. Fish. Res. Bd. Can. 28(1):59-64.

Tagatz, M. E. 1965. The fishery for blue crabs in the St. John's River, Florida, with special reference to fluctuations in yield between 1961-1962. U. S. Fish Wildl. Serv., Spec. Sci. Rept. 501:1-11.

Tinsley, I. J., R. Hague, and D. Schmedding. 1971. Binding of DDT to lecithin. Science 174(4005): 145-147.

Vonk, H. J. 1960. Digestion and metabolism. In T. H. Wateman (ed.), The Physiology of Crustacea. Vol. I. Metabolism and growth. Academic Press, Inc. New York. pp 291-316.

Walsh, G. E. 1972. Insecticides, herbicides, and polychlorinated biphenyls in estuaries. J. Wash. Acad. Sci. 62(2):122-139.

Wilson, A. J., Jr. 1968. Pesticide analytical manual for BCF contracting agencies. U. S. Bur. Comm. Fish., Biol. Lab., Gulf Breeze, Fla. 15p. 
Wilson, N. K. and W. E. Wilson. 1972. Complex equilibria involving DDT and model compounds for phospholipid and protein. Sci. Total Envir. 1:245-251.

Woodwell, G. M., P. P. Craig, and H. A. Johnson. 1971. DDT in the biosphere: where does it go? Science 174(4014): 1101-1107.

Woodwell, G. M., C. F. Wurster, Jr., and P. A. Isaacson. 1967. DDT residues in an East coast estuary: a case of biological concentration of a persistant insecticide. Science 156(3776): $821-823$.

Yarbrough, J. D. and M. R. Wells. 1971. Vertebrate insecticide resistance: the in vitro endrin effect on succinic dehydrogenase activity of endrin-resistant and susceptible mosquitofish. Bull. Envir. Contam. Toxicol. 6(2):171-176. 


\section{VITA}

Peter Francis Sheridan

Born in Washington, D. C., 20 June 1949. Graduated from Denis J. O'Connell High School, Arlington, Virginia, June, 1967. Received B.A. in Biology from the University of Virginia, Charlottesville, Virginia, June 1971. Enrolled as a graduate student in the Department of Marine Science, University of Virginia, September 1971. Research assistant in the Ichthyology Department, Virginia Institute of Marine Science. 